\title{
Experiential Metafunctional Analysis of Winston S. Churchill's Speech on Hitler's Invasion of the U.S.S.R.
}

\author{
Chen Liping ${ }^{1}$ \\ ${ }^{1}$ School of Foreign Languages, Guangdong University of Petrochemical Technology, Guangdong, China \\ Correspondence: Chen Liping, School of Foreign Languages, Guangdong University of Petrochemical \\ Technology, Maoming 525000, Guangdong, China. Tel: 86-139-2971-1518. E-mail: dorisno.1@163.com
}

Received: June 20, 2014 Accepted: July 21, 2014 Online Published: August 14, 2014

doi:10.5539/elt.v7n9p132 URL: http://dx.doi.org/10.5539/elt.v7n9p132

\begin{abstract}
According to Halliday, it is language that enables human beings to form the impression of experience, which consists of "goings-on"-happening, doing, sensing, meaning and being and becoming, either internally and externally. This is the experiential metafunction. With the focus on Transitivity, a political discourse has been studied from the perspective of Experiential Function. More uses of material and relational processes can make the speech more powerful and persuasive.
\end{abstract}

Keywords: experiential metafunction, political discourse, Winston S. Churchill

\section{Introduction}

The analysis of discourse, as Brown \& Yule (1983, 2000, p. 1) put it, is "necessarily the analysis of language in use". The time when discourse analysis emerged could be dated back to the 1950s. Harris (1952, quoted from Lin \& Yang, 2007, pp. 3-4) was the linguist who first used the term DISCOURSE ANALYSIS, which he maintained, could be applied to the study of a whole text so that the structuring above sentence could be discovered.

It was in 1960s that Halliday began to develop Systemic Functional Grammar (SFG), which is "a theory of meaning as choice, by which a language, or any other semiotic system, is interpreted as networks of interlocking options: 'either this, or that, or the other', 'either more like the one or more like the other', and so on" (Halliday, 1994, 2000, F40). But only the structural part of SFG, or functional grammar, is enough to "show how the options are realized" (ibid, F41).

According to Halliday's SFG, all adult language is organized around a small number of "functional components" which correspond to metafunctions (or the purposes which underlie all language use) and that these metafunctions have a systematic relationship with the lexicogrammar of the language (T. Bloor, \& M. Bloor, 1995, 2001, p. 9). We use language to talk about our experience of the world, including the worlds in our own minds, to describe events and states and the entities involved in them. We also use language to interact with other people, to establish and maintain relations with them, to influence their behaviour, to express our own viewpoint on things in the world, and to elicit or change theirs. Finally, in using language, we organize our messages in ways which indicate how they fit in with the other messages around them and with the wider context in which we are talking or writing. And the three categories above are used as the basis for exploring how meanings are created and understood because they allow the matching of particular types of function/meanings with particular types of wording (Thompson, 1996, 2000, p. 28). These three categories are known as ideational, interpersonal and textual metafunctions. When we focus mainly on what a message contains rather than the aim of the speaker, we examine the ideational function of language. Ideational function falls into two categories: experiential function and logical function. In this paper, the author will analyze the experiential function of a political discourse by Winston Churchill-Speech on Hitler's Invasion of the U.S.S.R. (hereafter referred to Speech) with the focus on transitivity.

\section{Transitivity}

Transitivity refers to a system for describing the whole clause, rather than just the Verb and its Object in traditional grammar (Thompson, 1996, 2000, p. 78). It shows how speakers imagine in language their mental picture of reality and how they account for their experience of the world around them. Transitivity focuses on the 
transmission of ideas, so it has everything to do with the experiential function of language. The way in which transitivity carries out this experiential function is expressed by process.

Based on SFG, each process is made up of three components: (i) the process itself; (ii) participants in the process; (iii) circumstances associated with the process (T. Bloor, \& M. Bloor, 1995, 2001, p. 107). According to the types of process in English, the process can be divided into material, relational, mental, behavioural, verbal and existential process. Material, relational, mental are the three main types of processes. They are the "principal" types in that they are the cornerstones of the grammar in its guise as a theory of experience, they present three distinct kinds of structural configuration, and they account for the majority of all clauses in a text. The other three processes are located at each of the boundaries. Behavioural processes share the characteristics of material and mental processes; verbal processes share those of mental and relational processes, while existential processes are between relational and material processes (Halliday, 1994, 2000, p. 138).

A politician usually employs various processes to achieve his/her purpose. And it becomes almost a rule that at least one process dominates in a particular discourse due to the particular register it belongs to.

Speech is broadcast on TV on the day when Hitler invaded the Soviet Union. Through this speech, Churchill wants to make the following points clear:

1) The Nazi regime is greedy, cruel, aggressive and is indistinguishable from the worst features of Communism. It possesses the worst form of human wickedness.

2) Hitler's massive slaughter onto Russia destroys the peaceful life and deprives Russian people of the human joys.

3) German's invasion of the USSR is only a prelude, and its next target will be Britain.

4) It's time for people all over the world, regardless of race, creed and party to unite together to fight against Nazism and protect their own countries.

To achieve this, Churchill needs to tell his audience the evils that Nazi has committed, what it is doing to Russia now and his determination of destroying Hitler's dictatorship. He needs to illustrate his arguments from different aspects, so different processes are employed to achieve this purpose. The number of all processes and the percentage of different processes can be shown in the following table.

Table 1. Proportion of process types in Speech

\begin{tabular}{lccc}
\hline Process Type & Number of processes & Total of processes & Percentage of processes \\
\hline Material process & 33 & $37.5 \%$ \\
Relational process & 23 & 88 & $26.1 \%$ \\
Mental process & 20 & $22.7 \%$ \\
Verbal process & 8 & $9.1 \%$ \\
Behavioural process & 2 & $2.3 \%$ \\
Existential process & 2 & $2.3 \%$ \\
\hline
\end{tabular}

From the above Table, we can see that there are altogether 88 processes in Speech. And it can be seen clearly that the material process $(37.5 \%)$, relational process $(26.1 \%)$ and mental process $(22.7 \%)$ make up the majority $(86.3 \%)$ of the percentage. Behavioural process ranks fourth, making up $9.1 \%$. Verbal process and existential process, which share the same percentage in the discourse, are the least used, accounting for $4.6 \%$ of the total process types. Why are material processes in the dominant position? The reason is that a powerful political speech always focuses on stating the facts objectively, conducting reasoning logically, or expressing feelings emotionally. And material processes serve these functions.

Material process is the most frequently-used type in political speeches, especially persuasive speech like Speech. In this speech, the evils that Nazi regime has done are enumerated one by one: what they have committed in the past and what they are doing to Russia now. After putting this clear, Churchill goes on to show his determination to eliminate Nazism. All this involves the use of material process. Look at the following paragraphs from Speech.

(1) When I awoke on the morning of Sunday, the 22 $2^{\text {nd }}$, the news was brought (Material) to me of Hitler's 
invasion of Russia. This changed (Material) conviction into certainty. I had (Relational) not the slightest doubt where our duty and our policy lay. Nor indeed what to say. There only remained (Existential) the task of composing it. I asked (Verbal) that notice should immediately be given that I would broad-cast at 9 o'clock that night. Presently General Dill, who had hastened down from London, came (Material) into my bedroom with detailed news. The Germans had invaded (Material) Russia on an enormous front, had surprised (Behavioural) a large portion of the Soviet Air Force grounded on the airfields, and seemed (Mental) to be driving forward with great rapidity and violence. The Chief of the Imperial General Staff added (Material), "I suppose they will be rounded up in hordes."

(2) We are resolved (Mental) to destroy Hitler and every vestige of the Nazi regime. From this nothing will turn (Material) us-nothing. We will never parley (Material), we will never negotiate (Material) with Hitler or any of his gang. We shall fight (Material) him by land, we shall fight (Material) him by sea, we shall fight (Material) him in the air, until, with God's help, we have rid (Material) the earth of his shadow and liberated (Material) its people from his yoke.

In example (1), there are 10 processes in all. Out of them, relational, mental, behavioural, verbal and existential process each occurs once respectively, while the other five are material processes, accounting for $50 \%$ of the total processes. This paragraph mainly states out the fact that Hitler has invaded Russia objectively, which arouses people's sympathy towards Russians and indignation against Hitler's dictatorship.

In example (2), there are altogether 9 processes, out of which there is only 1 mental process, the other 8 are all material processes, which make up $89 \%$ of the total processes. By using such a high percentage of material processes, Churchill shows his firm determination to eliminate Hitler and Nazi regime from the earth.

Material processes may have goals or may not. Transitivity analysis shows that most of the material processes in these two examples have goals. The fact that Hitler did evils to Russia and Churchill's determination of eliminating Hitler and Nazi regime are reflected in the use of language that has Actors and Goals, which involve the two conflicting parties.

Relational processes describe the relationship of people and things in a discourse. In English political speeches, the relational processes are often used in explaining some abstract political concepts, elaborating the relationship between political powers or between other entities. In Speech, the relational processes take up $26.1 \%$ of all the processes. Look at the following extracts from Speech.

(1) "The Nazi regime is (Relational) indistinguishable from the worst features of Communism. It is (Relational) devoid of all theme and principle except appetite and racial domination.

(2) This is (Relational) no class war. It is (Relational) a war in which the whole British Empire and Commonwealth of Nations is engaged without distinction of race, creed, or party. It is (Relational) not for me to speak of the action of the United States, but this I will say (Verbal): If Hitler imagines that his attack on Soviet Russia will cause the slightest division of aims or slackening of effort in the great democracies who are resolved upon his doom, he is (Relational) woefully mistaken.

(3) Any man or State who fights against Nazism will have (Relational) our aid. Any man or State who marches with Hitler is (Relational) our foe... That is (Relational) our policy and that is (Relational) our declaration. It follows (Relational) therefore that we shall give whatever help we can to Russia and to the Russian people."

In the above extracts, (1) describes the evil nature of Nazi regime, which arouses people's hatred and indignation against it. (2) tells us that the war against Nazi regime is just. The purpose for Churchill to make this speech is to urge British people into action to destroy Hitler and Nazi regime, so it is necessary to highlight the evil nature of them and justify the war against them. (3) draws a clear line between the two groups: one is our friend, and the other is our foe. It shows us the relationship: To friends, we will give our aid, but to enemies, we'll try every effort to destroy them.

In order to explain clearly the relation among the different conceptions, we further divide the relational processes into more specific ones: attributive process and Value/Token process. In the former, an entity has some quality ascribed or attributed to it. While in the latter, one entity is being used to identify another. The relational processes in (1) are attributive because Nazi regime is the Carrier and the Attribute shows the quality of it. In (2) and (3), all processes are Token-Value processes because the two participants involved function as Identifier and Identified.

Mental processes are used to express the politician's political belief, ambition, hope, their expectation and feelings. Look at the following extracts from Speech: 
(1) I knew (Mental) that we all felt the same on this issue

(2) I see (Mental) the Russian soldiers standing.... I see (Mental) them guarding.... I see (Mental) the ten thousand villages of Russia... I see (Mental) advancing.... I see (Mental) also.... I see (Mental) the German bombers and fighters....

(3) Behind all this glare, behind all this storm, I see (Mental) that small group of villainous men...

(4) I have to (Mental) declare t...,- - and I feel (Mental) sure.... I have to (Mental) make the declaration, but can you doubt (Mental) what our policy will be?"

Except one (but can you doubt what our policy will be?), all the other mental processes here have "I" as the sensor. In the political speech, the speaker wants to influence the audience to accept his opinion. So, firstly, he must tell the listeners his own point of view. As the Prime Minister, Churchill has the authority in political affairs. By using a series of "I see..." clauses to describe what is happening on Russia's land: the Russian soldiers are guarding their home and their families are praying for them, while the brutal German armies are marching onto their land, Churchill creates a vivid picture before his listeners as if they were the witnesses of this scene. With the picture can be seen, the sound can be heard, people believe that the savage act is just being shown on. Thus the urgency and necessity of the war is highlighted.

Verbal processes are processes of saying and cover any kind of symbolic exchange of meaning (Halliday, 1994, 2000, p. 140). It is reasonable for a political speech to have a certain percentage of verbal processes since one of its characteristics is informative. Look at the following extracts from Speech.

(1) I asked (Verbal) that notice should immediately be given that I would broad-cast at 9 o'clock that night.

(2) During dinner Mr. Churchill said (Verbal) that a German attack on Russia was now certain.

(3) The P. M. had always said (Verbal) that he was never to be woken up for anything but Invasion (of England).

(4) When I spoke a few minutes ago of Hitler's bloodlust and the hateful appetites which have impelled or lured him on his Russian adventure I said (Verbal) there was one deeper motive behind his outrage.

(5) Winant said (Verbal) the same would be true of the U.S.A

(6) I asked (Verbal) whether for him, the arch anti-Communist, this was not bowing down in the House of Rimmon. Mr. Churchill replied (Verbal), "Not at all. I have only one purpose, the destruction of Hitler, and my life is much simplified thereby."

In example (1), (2), (3) and (4), the Sayer is Churchill; the Receivers are his assistants or other officials. The Verbiage is about his opinion of Hitler's invasion and the action he is to take. In example (5) and (6), the Sayer is his assistant or other official, and the Receiver is Churchill. The Verbiage is also about Hitler's invasion. On such an important matter, Churchill has to discuss and exchange information with his assistants and officials. The verbal processes here are realized through the verbs say, ask and reply, which are the most frequently-used words in daily conversation. Therefore, the speech becomes friendlier and more acceptable to the audience.

Each political speech has its specific political aim. The speaker expresses his idea to persuade the audience only through his speech. The more objective the speech appears, the more persuasion it can attain. The material and relational processes are most often chosen because they present the statements of reality from the point of view of onlookers. So they seem to be more objective than other processes. Mental processes also play a very important role in expressing the politician's ideas in this speech. By telling the listeners what he has seen and thought about the current situation, Churchill makes them believe what he has stated is true; hence the speech is made more convincing.

A skillful politician always uses different processes to achieve his political aims. In this speech, apart from material, relational and mental processes, which hold up a large proportion of the total, the speaker also uses other three processes, that is, verbal, behavioural and existential processes, which are less used compared to the former three. It is the combination of these processes that makes this speech powerful and persuasive.

\section{Conclusion}

A prominent feature of political discourse is persuasion, and the persuasive intension of the speaker or writer can be researched through the language he employs. Through the analysis of transitivity, we find that Churchill tends to use more material (37.5\%) and relational processes (26.1\%). According to Halliday, material processes are the processes of doing. They express the notion that some entity "does" something — which may be done "to" some other entity (Halliday, 1994, 2000, p. 110). The main purpose of Churchill's Speech is to persuade British people to support his decision of assisting Russia and fighting against Hitler. Therefore, Churchill has to mention the 
savage acts that the gang of Hitler has committed in the past or present quite often, so that the audience are quite aware of the fact, which arouses their sympathy towards Russians and indignation to Nazi regime. The material processes do serve this purpose. Relational process has the second largest proportion of $26.1 \%$ in Speech. In relational processes, something is being said to "be" something else (Halliday, 1994, 2000, p. 119). In this speech, by using relational processes, Churchill makes it clear to the audience how evil the nature of Nazism is, thus the war against it is justified. Material processes and relational processes seem to state the facts from the view of the onlookers, so they are more objective than other processes. By adopting more material and relational processes, Churchill successfully makes his people support his political viewpoints.

\section{Acknowledgements}

The author would like to acknowledge the valuable suggestions and expert guidance provided by Professor Chang Chenguang and Professor Huang Guowen, Former and Present Deans of School of Foreign Languages, Sun Yat-sen University, China, who have always encouraged the author all the way through the work.

\section{References}

Bloor, T., \& Bloor, M. (1995, 2001). The Functional Analysis of English: A Hallidayan Approach. Beijing: Foreign Language Teaching and Research Press.

Brown, G., \& Yule, G. (1983, 2000). Discourse Analysis. Beijing: Foreign Language Teaching and Research Press.

Halliday, M. A. K. (1994, 2000). An Introduction to Functional Grammar. Beijing: Foreign Language Teaching and Research Press.

Thompson, G. (1996, 2000). Introducing Functional Grammar. Beijing: Foreign Language Teaching and Research Press.

Lin, W., \& Yang, Y. (2007). Yingyu Yupian Fenxi. Shanghai: Fudan University Press.

\section{Copyrights}

Copyright for this article is retained by the author (s), with first publication rights granted to the journal.

This is an open-access article distributed under the terms and conditions of the Creative Commons Attribution license (http://creativecommons.org/licenses/by/3.0/). 